\title{
Konservasi Alam Berbasis Kearifan Lokal Suku Kokoda di Kepulauan Ugar, Kabupaten Fakfak, Papua Barat
}

\author{
(Conservation Based on Local Wisdom Practised by the Kokoda Tribe in the Ugar Islands, Fakfak \\ Regency, West Papua)
}

Reza Saputra

Balai Besar Konservasi Sumber Daya Alam Papua Barat, Kementerian Lingkungan Hidup dan Kehutanan, Jalan Klamono KM 16, Sorong 98417, Provinsi Papua Barat, Indonesia. Email korespondensi: reza.saputraa21@gmail.com

(Article History: Received 8 October 2020; Revised 2 November 2020; Accepted 10 November 2020)

\section{ABSTRAK}

Penelitian eksplorasi mengenai konservasi berbasis kearifan lokal Suku Kokoda di Kepulauan Ugar, Kabupaten Fakfak, Papua Barat telah dilaksanakan pada bulan Mei 2016. Tujuan penelitian ini untuk mengetahui peran jenis kearifan lokal terhadap alam sebagai penyangga kehidupan masyarakat Suku Kokoda. Aspek penelitian yang diamati yaitu kearifan lokal yang berdampak pada konservasi tingkat spesies atau ekosistem. Data yang didapat berasal dari wawancara semistruktural kepada 10 informan kunci. Pada penelitian ini terdapat tiga kearifan lokal yang teramati, yaitu sasi laut, hutan keramat, dan apotik hidup. Hasil penelitian menunjukan kearifan lokal yang ada pada suku Kokoda berperan penting dalam kelestarian alam di wilayah tersebut.

Kata kunci: Kearifan lokal; Konservasi; Papua Barat; Suku Kokoda

\section{ABSTRACT}

Exploration research on the local wisdom-based conservation of the Kokoda Tribe in the Ugar Islands, Fakfak Regency, West Papua, was conducted in May 2016. This research aimed to determine the role of Kokoda Tribe's local wisdom in preserving nature. The research aspect observed was local wisdom, which impacted conservation at the species or ecosystem level. The data obtained from semistructured interviews of 10 key informants. In this research, three local wisdoms were observed, i.e. sasi laut, hutan keramat, and apotik hidup. The results show that the local wisdom of the Kokoda tribe plays an essential role in preserving nature.

Keywords: Local Wisdom; Conservation; West Papua; Kokoda Tribe

\section{PENDAHULUAN}

Sejak zaman prasejarah, alam dan manusia saling memiliki hubungan satu sama lain. Manusia membutuhkan alam untuk menunjang kebutuhan hidup seharihari. Hal tersebut dikarenakan alam memiliki kebutuhan dasar yang diperlukan manusia untuk bertahan hidup, seperti air, energi, makanan, udara, dan perlindungan. Sebagai timbal balik, manusia harus menjaga alam agar tetap mendapatkan kebutuhan dasar tersebut. Hubungan antara keduanya seringkali membuat suatu interaksi yang kuat untuk menunjang satu sama lain (Satyananda et al. 2013). Interaksi tersebut umumnya menghasilkan suatu kearifan lokal yang memiliki timbal balik yang positif antara keduanya. Misalnya suku yang ada di pedalaman Papua, yaitu suku Yali yang masih sangat bergantung pada hutan. Suku tersebut harus menjaga hutan agar tetap lestari, karena jika hutan tersebut rusak mereka tidak akan mendapat makanan lagi (Milliken 2002).

Terdapat beraneka macam kearifan lokal yang ada pada suatu masyarakat lokal, salah satunya yaitu kearifan lokal yang berdampak pada konservasi alam (Purnawibowo 2014). Suku Helong di Nusa Tenggara Timur merupakan salah satu contoh yang memiliki kearifan lokal berupa larangan memasuki mata air sakral, hanya ketua adat yang diperbolehkan untuk memasukinya pada saat ritual meminta hujan (Satyananda et al. 2013). Setelah diteliti lebih lanjut, mata air merupakan sumber kehidupan yang berperan 
penting dalam proses hidrologis, sungaisungai yang berasal dari mata air berperan dalam membawa air untuk kehidupan seharihari masyarakat. Jika setiap orang bebas untuk memasuki sumber mata air tersebut, dikhawatirkan akan terjadi pencemaran, yang pada akhirnya akan berdampak pada masyarakat suku Helong itu sendiri (Satyananda et al. 2013). Mengetahui kearifan lokal berbasis konservasi dapat menjadi salah satu referensi untuk terus melakukan konservasi secara serentak di seluruh pelosok daerah. Karena pada dasarnya, konservasi berbasis kearifan lokal lebih mudah diterima oleh masyarakat lokal (Kuwati et al. 2014).

Suku Kokoda merupakan salah satu suku di Papua Barat yang memiliki persebaran cukup luas, yakni meliputi Kabupaten Sorong, Sorong Selatan, dan Kabupaten Fakfak. Penelitian ini fokus mengamati kearifan lokal suku Kokoda yang ada di Kepulauan Ugar, Kabupaten Fakfak. Secara geografis, Kepulauan Ugar terletak di antara $02^{\circ} 38^{\prime} 19,3$ " BT dan $132^{\circ} 26^{\prime} 33,3$ " LS dengan luas wilayah sekitar 200 hektar dan jumlah penduduk sebanyak 233 orang. Secara umum, budaya yang ada pada suku Kokoda masih cukup terjaga kelestariannya (Saputra 2016), sehingga perlu dilakukan penelitian tentang konservasi alam berbasis kearifan lokal yang dilakukan oleh suku Kokoda. Tujuan penelitian ini adalah untuk mengkaji peran jenis kearifan lokal tersebut terhadap alam sebagai penyangga kehidupan masyarakat Suku Kokoda.

\section{METODE}

\section{Tempat dan Waktu}

Penelitian konservasi berbasis kearifan lokal yang dipraktikan oleh Suku Kokoda dilakukan di Kampung Ugar, Kepulauan Ugar, Pulau Ogasmuni, Distrik Kokas, Kabupaten Fakfak pada bulan Mei 2019 (Gambar 1).

\section{Cara Kerja}

Pengumpulan data terbagi menjadi dua tahapan, pengumpulan data primer dan pengumpulan data sekunder. Data primer didapat dari wawancara semi struktural kepada 10 informan kunci (Tabel 1), sedangkan data sekunder didapat dari instansi pemerintah terkait dan studi pustaka di internet mengenai kearifan lokal sukusuku yang ada di Papua Barat. Selanjutnya, data dianalisis secara kualitatif dengan berfokus pada konservasi berbasis kearifan lokal yang ada di Suku Kokoda dan dikaitkan dengan beberapa permasalahan konservasi.

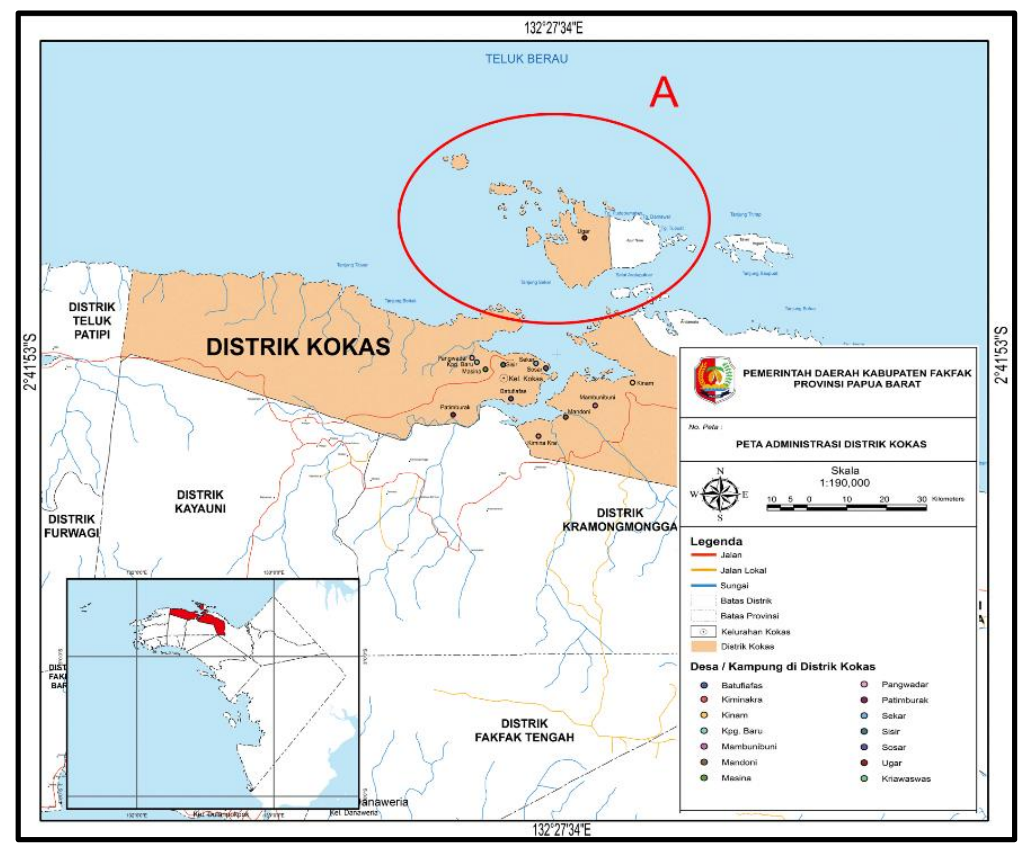

Gambar 1. Peta Administrasi Distrik Kokas, Kabupaten Fakfak. (A) Lokasi penelitian yaitu Kepulauan Ugar. 
Tabel 1. Daftar informan kunci dalam penelitian

\begin{tabular}{rllll}
\hline No & Nama Informan & $\begin{array}{c}\text { Jenis } \\
\text { Kelamin }\end{array}$ & Umur & \multicolumn{1}{c}{ Pekerjaan } \\
\hline 1 & Rogaya Kopauruma & Perempuan & 50 thn & Ibu Rumah Tangga \\
2 & Yunus & Laki-laki & 38 thn & Sekretaris Desa dan Nelayan \\
3 & Syaraf Biaruma & Laki-laki & 67 thn & Kepala Adat Suku Kokoda \\
4 & Hasan Mambrasar & Laki-laki & 60 thn & Nelayan \\
5 & Andi Bauw & Laki-laki & 40 thn & Nelayan \\
6 & Afifa Biaruma & Perempuan & 26 thn & Ibu Rumah Tangga (Istri Kepala Adat) \\
7 & Rouf Rumagesan & Laki-laki & 49 thn & Nelayan \\
8 & Sahara Biaruma & Perempuan & 32 thn & Ibu Rumah Tangga \\
9 & Wahit Biawa & Laki-laki & 30 thn & Nelayan \\
10 & Isak & Laki-laki & 48 thn & Nelayan \\
\hline
\end{tabular}

\section{HASIL DAN PEMBAHASAN}

Penelitian berhasil memperoleh tiga kearifan lokal suku Kokoda yang berkaitan dengan konservasi, yaitu sasi laut, hutan keramat, dan apotik hidup.

\section{Sasi laut}

Menurut beberapa informan kunci, budaya sasi laut merupakan budaya yang diturunkan oleh nenek moyang untuk mengatur hasil panen laut. Pengaturan tersebut berupa pembagian wilayah tangkap pada periode waktu yang berbeda. Biasanya terbagi menjadi beberapa wilayah tangkap, yang tiap wilayah tangkap tersebut hanya boleh diakses pada waktu tertentu. Ada juga pengaturan berdasarkan jenis hasil tangkap pada periode waktu yang berbeda. Pada suku Kokoda, kedua jenis budaya sasi laut tersebut masih dijalankan. Karena masyarakat lokal percaya jika mereka menjalankan sasi laut, hasil tangkapan laut mereka akan semakin banyak karena diberkati oleh alam.

Budaya sasi laut yang ada di suku Kokoda dibuka oleh ketua adat, dengan cara melakukan ritual sesaji di tempat yang akan dilakukan sasi laut. Selesai ritual, pada waktu subuh esok harinya seluruh masyarakat mandi di air laut dengan membawa alat tangkap hewan laut seperti alat pancing, jaring ikan, tombak ikan, dan lain-lain. Selanjutnya, tempat yang dilakukan sasi laut tadi tidak boleh dipanen hasil lautnya selama 6 bulan oleh semua masyarakat. Biasanya terbagi menjadi dua wilayah, wilayah utara dan selatan. Ketika wilayah utara sedang diadakan sasi laut (tidak boleh dipanen), maka wilayah selatan diperbolehkan untuk dipanen, begitu pula sebaliknya. Sasi laut berupa jenis tangkapan juga dilakukan setiap enam bulan. Contohnya hasil tangkapan berupa kepiting, lobster, dan teripang hanya boleh dipanen selama enam bulan pada tiap tahunnya dan pengambilannya diharuskan dengan cara tradisional tanpa merusak ekosistem. Kepiting atau lobster yang sedang bertelur juga tidak boleh dipanen meskipun di luar periode sasi laut. Hal tersebut menjadi pantangan yang jika dilanggar akan mendapat musibah.

Kearifan lokal sasi laut ini menjadikan ekosistem laut lebih terjaga, karena terdapat pembatasan dalam pengambilan sumber daya laut (Kuwati et al. 2014). Sehingga, terjadi proses regenerasi ekosistem terlebih dahulu. Jika proses regenerasi ekosistem atau sasi laut ini tidak dijalankan, dikhawatirkan akan terjadi eksploitasi sumber daya laut yang berlebihan dan kepunahan beberapa spesies hewan laut. Sasi laut merupakan salah satu kearifan lokal dengan tipe konservasi pada tingkat ekosistem. Terbukti dengan diterapkannya budaya sasi laut ini, Kepulauan Ugar menjadi salah satu pemasok ikan paling besar di Kabupaten Fakfak (Kepala Dinas Perikanan Kabupaten Fakfak, Komunikasi Pribadi, 18 Februari 2016). 


\section{Hutan Keramat}

Pada bagian timur Kepulauan Ugar, terdapat beberapa hutan keramat yang harus disertai izin dari ketua adat jika ingin memasukinya. Proses perizinannya terbagi menjadi dua tahapan ritual. Pertama, yaitu ritual penyerahan sesaji berupa pinang, sirih, kapur, dan tembakau di pohon keramat. Kedua, yaitu ritual pengikatan tali merah oleh orang yang ingin masuk kawasan di pintu masuk hutan keramat. Hal tersebut dipercaya sebagai bentuk ikatan persaudaraan antara leluhur dengan orang yang ingin masuk kawasan agar dijaga oleh roh leluhur dan diberikan keselamatan.

Menurut beberapa informan kunci, jika ada yang melanggar adat tersebut dan masuk hutan keramat tanpa izin, maka orang yang melanggar itu akan mendapat sanksi sendiri. Seringkali sanksi tersebut datang dari roh leluhur berupa kesurupan. Pernah pada tahun 2015, terjadi peristiwa kesurupan masal bagi orang yang tidak mengikatkan tali merah. Menurut ketua adat, kesurupan adalah sanksi paling ringan. Pernah ada juga sebelumnya yang meninggal, bahkan hilang tanpa diketemukan jasadnya.

Ketakutan akan sanksi tersebut membuat masyarakat lokal dan pendatang lebih berhati-hati jika akan memasuki hutan keramat. Hal tersebut secara tidak langsung menjadikan hutan keramat sebagai kawasan yang terlindungi dan lestari (Woretma 2013). Hampir sama dengan fungsi cagar alam yang digunakan sebagai area konservasi in situ, yang bertujuan untuk menjaga ekosistem dan keanekaragaman hayati yang ada di dalamnya. Jadi secara tidak langsung dan tidak disadari, masyarakat lokal berperan aktif dalam konservasi di level ekosistem. Lebih dari itu, konsep konservasi seperti ini lebih efektif dan diterima oleh masyarakat lokal dibanding cagar alam yang dikelola oleh pemerintah, karena pada pengamatan di lapangan, masih terdapat masyarakat lokal yang menebang pohon di area hutan yang sudah ditetapkan sebagai cagar alam.

\section{Apotik Hidup}

Terdapat kearifan lokal yang sangat penting bagi kelestarian tumbuhan obat, yakni apotik hidup. Pada bagian tengah Kampung Ugar, terdapat area sekitar $25 \mathrm{~m}^{2}$ yang disebut sebagai apotik hidup oleh masyarakat lokal. Meskipun sebagian besar tanaman yang dimanfaatkan untuk obat berasal dari hutan, namun ada juga beberapa tumbuhan yang dibudidayakan di apotik hidup. Tumbuhan yang ditanam di apotik hidup sebagian besar adalah tanaman yang dimanfaatkan bagian akar, rhizoma, batang, atau yang seluruh bagian tumbuhannya digunakan untuk obat. Contoh diantaranya yakni tanaman Zingiber officinale Roscoe (Abascal \& Yarnell 2009), Cymbopogon citratus (DC.) Stapf (Avoseh et al. 2015), Phyllanthus niruri L. (Narendra et al. 2012), Curcuma longa L. (Labban 2014), dan lainlain.

Pada tumbuhan obat yang berasal dari hutan, umumnya bagian yang digunakan adalah daun dan ranting. Sedangkan untuk batang jarang sekali dipakai. Contohnya Kayu Ular (Picrasma javanica Blume.) atau dengan bahasa lokal disebut Gorai. Tumbuhan ini merupakan obat malaria yang umum diketahui oleh sebagian besar masyarakat di Papua. Umumnya bagian yang digunakan untuk pengobatan ialah batang pohon karena memiliki kandungan metabolit sekunder paling banyak (Pratiwi et al. 2007). Namun cara pemanfaatan gorai pada Suku Kokoda berbeda, yakni bagian yang digunakan adalah daun dan ranting. Menurut ketua adat dan beberapa tokoh pengobatan, bagian yang dipercaya dapat mengobati penyakit adalah bagian daun dan ranting, sedangkan bagian batang tidak dipercaya dapat digunakan sebagai obat. Ilmu tersebut merupakan resep yang diwariskan secara turun temurun dari leluhur atau nenek moyang.

Setelah ditelaah lebih lanjut, pemanfaatan tumbuhan yang diambil bagian batang atau akarnya dapat membunuh tumbuhan tersebut. Mengingat letak geografis yang berupa kepulauan dan terbatasnya luas wilayah desa Suku Kokoda, 
apotik hidup adalah solusi bijaksana dan cerdas untuk menjaga kelestarian tumbuhan tersebut di alam. Ilmu pengobatan tradisional yang diturunkan dari nenek moyang dan diterapkan pada kehidupan
Suku Kokoda sehari-hari ternyata memiliki nilai konservasi. Secara tidak sadar, masyarakat lokal Suku Kokoda telah berperan aktif dalam konservasi pada level spesies.

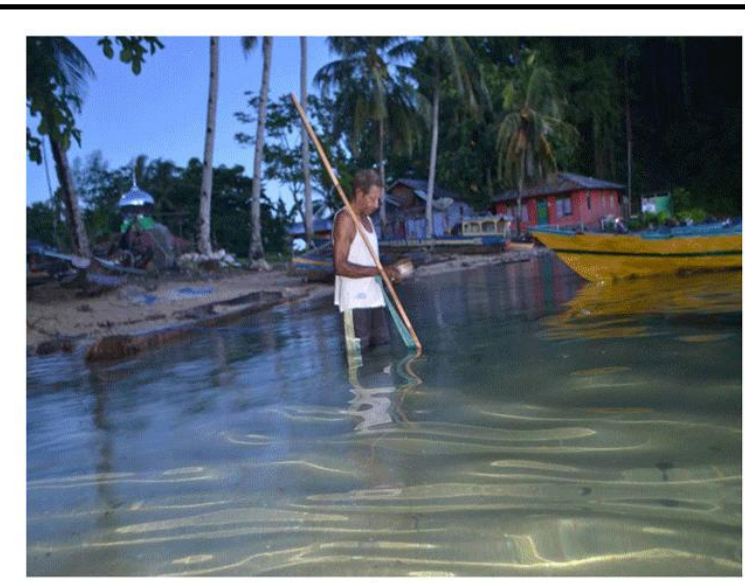

A

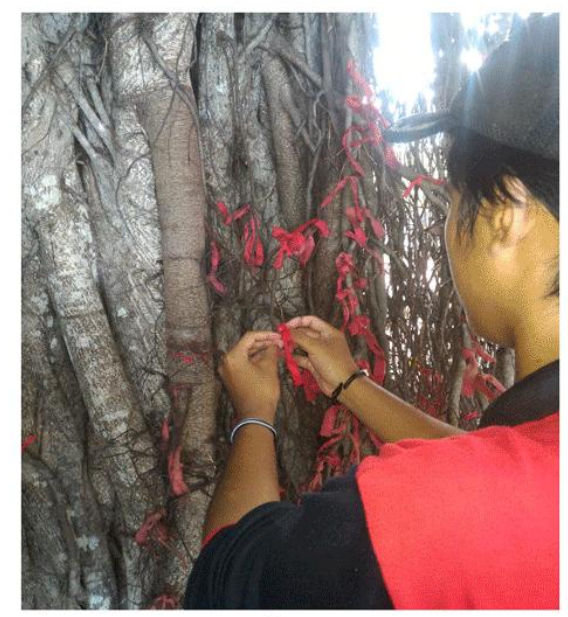

C

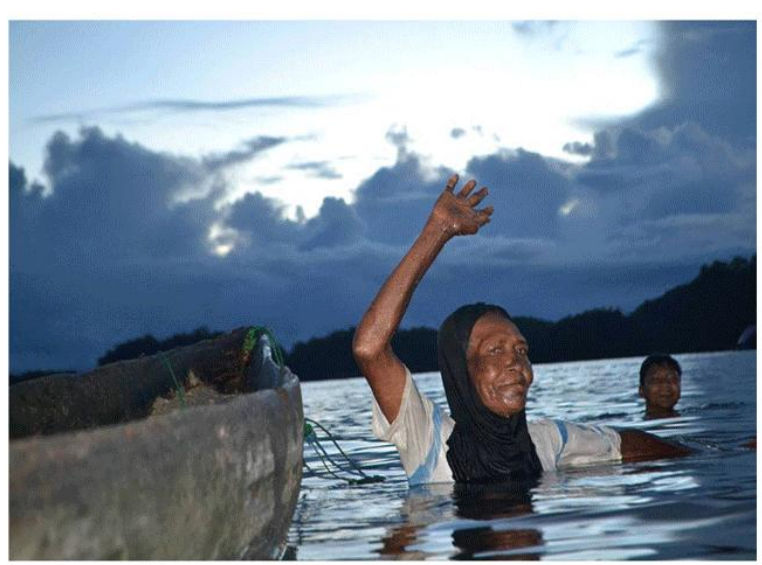

B

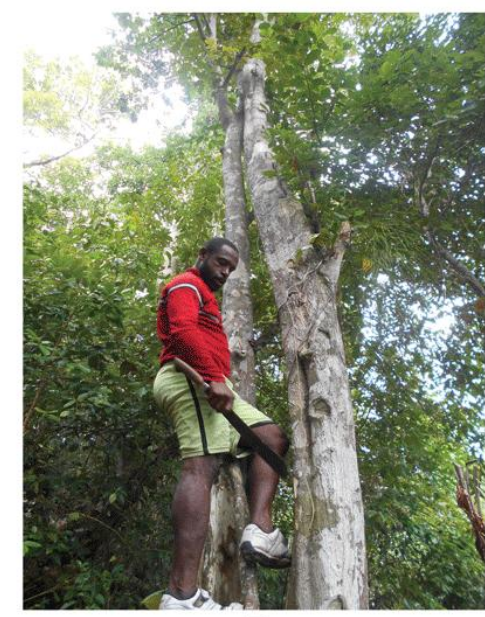

D

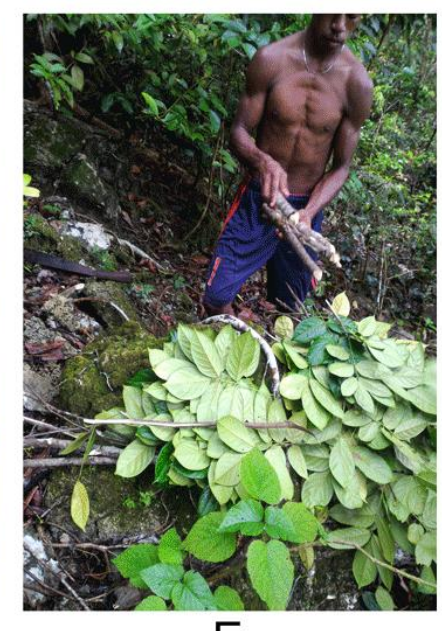

E

Gambar 2. Konservasi berbasis kearifan lokal yang ada pada suku Kokoda. (A) \& (B) Masyarakat membawa alat pancing ketika mandi pada acara pembukaan sasi laut. (C) Mengikat tali merah pada pintu masuk hutan keramat. (D) Memanjat untuk mengambil daun atau ranting gorai, dan (E) daun dan ranting kayu ular yang dimanfaatkan sebagai obat pegal-pegal, nafsu makan, stamina, dan malaria.

\section{KESIMPULAN}

Penelitian eksplorasi mengenai konservasi berbasis kearifan lokal yang dilakukan oleh Suku Kokoda di Kepualauan Ugar, Kabupaten Fakfak, Papua Barat mendapatkan tiga kearifan lokal, yaitu sasi laut, hutan keramat, dan apotik hidup. Masing-masing kearifan lokal memiliki nilai konservasi yang secara tidak sadar telah dijalankan oleh suku
Kokoda sejak dahulu. Konsep konservasi seperti ini lebih efektif dan diterima oleh masyarakat lokal. Sasi laut dan hutan keramat merupakan konservasi tingkat ekosistem, sedangkan apotik hidup merupakan konservasi tingkat spesies.

\section{UCAPAN TERIMA KASIH}

Penulis mengucapkan terima kasih kepada Ekspedisi NKRI 2016 Koridor 
Papua Barat yang telah memfasilitasi penelitian ini. Isack Berth Samori, selaku Kepala Resort KSDA Kabupaten Fakfak yang telah membantu penulis ketika di lapangan. Inggit Puji Astuti, selaku Ketua Tenaga Ahli Tim Flora Fauna dan kepada rekan-rekan semua yang terlibat dalam penelitian ini.

\section{DAFTAR PUSTAKA}

Abascal K \& Yarnell E (2009) Clinical uses of Zingiber officinale (Ginger). Alternative and Complementary Therapies 15(5): 231 - 237. doi: 10.1089/act.2009.15501.

Avoseh O, Oyedeji O, Rungqu P, NkehChungag B \& Oyedeji A (2015) Cymbopogon Species: Ethnopharmacology, Phytochemistry and the Pharmacological Importance. Molecules 20: $7438 \quad-7453$. doi:10.3390/molecules20057438.

Kuwati, Martosupono M, Mangimbulude JC (2014) Konservasi berbasis kearifan lokal (Studi kasus; Sasi laut di Kabupaten Raja Ampat). Prosiding Seminar Nasional Raja Ampat Waisai. pp A9 - A15.

Labban L (2014) Medicinal and pharmacological properties of Turmeric (Curcuma longa): A review. Int J Pharm Biomed Sci. 5(1):17-23.

Milliken W (2002) Ethnobotany of the Yali of West Papua. Royal Botanic Garden, Edinburgh.
Narendra K, Swathi J, Sowjanya KM, Satya AK (2012) Phyllanthus niruri: A Review on its Ethno Botanical, Phytochemical and Pharmacological Profile. Journal of Pharmacy Research 5(9): 4681 - 4691.

Pratiwi M, Harapini \& Chairul (2007) Antimalaria in-vivo activity test of ki pahit extract (Picrasma javanica) to mice infected with Plasmodium berghei. Biodiversitas 8(2): $111-113$.

Purnawibowo S (2014) Konservasi berbasis kearifan lokal di Situs Benteng Puteri Hijau, Deli Serdang, Sumatera Utara. Jurnal Konservasi Cagar Budaya Borobudur 8(2): 32-41.

Saputra R (2016) Studi Etnobotani pada Suku Kokoda, Pulau Ogasmuni, Kabupaten Fakfak, Papua Barat. Skripsi. Program Studi Biologi, FMIPA, Universitas Indonesia. Depok. Satyananda IM, Sanjaya IPK, Dwikayana K \& Nitbani SH (2013) Kearifan lokal Suku Helong di Pulau Semau Kabupaten Kupang Nusa Tenggara Timur. Penerbit Ombak Dua, Yogyakarta.

Woretma M (2013) Keanekaragaman tumbuhan pangan dan obat pada masyarakat suku Mbaham Mata di Kampung Werabuan, Kabupaten Fakfak. Skripsi. Fakultas Kehutanan IPB, Bogor. 